\title{
Optimal Stocking Density of Vannamei Shrimp Lytopenaeus vannamei at Low Salinity Using Spherical Tarpaulin Pond
}

\author{
Eulis Marlina*, Dwi Puji Hartono \\ Aquaculture Study Program \\ Politeknik Negeri Lampung \\ Bandar Lampung, Indonesia \\ *eulismarlina@polinela.ac.id,dwiph@polinela.ac.id
}

\author{
Imelda Panjaitan \\ Animal Production Study Program \\ Politeknik Negeri Lampung \\ Bandar Lampung, Indonesia \\ imelpolinela27@polinela.ac.id
}

\begin{abstract}
The worsening environmental conditions cause disease attack on shrimp farming can not be avoided, the high cost of vannamei shrimp production resulting in shrimp farming can only be owned by certain circles. Therefore, it is necessary to find alternative shrimp farming in order to avoid disease and affordable cost to increase production. The farming of vannamei shrimp (Lytopenaeus vannamei) using tarpaulin is expected to minimize production cost, utilize narrow land and far from sea water source, and facilitate control of shrimp health at the time of cultivation. The aim of this research is to obtain the data of shrimp average weight (Mean Body Weight), survival rate and best Food Conversion Ratio for vannamei shrimp at low salinity using container of $1 \mathrm{~m}^{3}$ tarpaulin pond with three different densities which are: A (density of 175 tails $\left./ \mathrm{m}^{3}\right), B\left(225\right.$ tails $\left./ \mathrm{m}^{3}\right)$ and $C\left(275\right.$ tails $\left./ \mathrm{m}^{3}\right)$ with three replications. Shrimp seeds used were PL 11 (post larvae) which acclimatized prior to the treatment along with the decrease of media salinity until 5-10 ppt for 7 days, then shrimp seeds were placed on the tarpaulin pond according to the treatment. Maintenance was performed for 60 days with Feeding Rate of $5-10 \%$ and 4 times/day feeding frequency. Based on the result of the research, it was found that the optimal stocking density of shrimp was shrimp cultivation with the density of 175 tails $/ \mathrm{m}^{3}$ with Mean Body Weight (MBW) value of 10,52 $\pm 0,2$ gram, Survival Rate $(S R)$ of $91,39 \pm 1,0 \%$ and Food Conversion Ratio (FCR) of 1,6 \pm 0,1. Based on the Tukey test $(<0.05)$ showed that stocking density had an effect on shrimp average weight and vannamei shrimp survival rate.
\end{abstract}

Keywords-tarpaulin pond, low salinity, density, Lytopenaeus vannamei

\section{INTRODUCTION}

Vannamei (Litopenaeus vannamei) are shrimp from the Pacific Coast of Latin America (South Peru and North Mexico) which officially entered Indonesia in 2001 [1]. The advantages of vannamei are able to live in the water column so that it can be cultivated with high density, faster growth, resistant to disease attacks and short maintenance cycles between 90-100 days. Thus, it is a commodity that has high economic value [2].

Environmental carrying capacity is currently experiencing a setback due to pollution, improper cultivation management. Hence, the spread of disease is difficult to avoid as a result affecting the amount of production and decreasing survival rates of vannamei shrimp and high losses.

Vannamei is euryhaline, so it becomes a promising commodity to be cultivated in low salinity [3]. This provides business opportunities for coastal to land communities, with low costs, easy to control and still profitable. Alternative cultivation facilities can use a tarpaulin pond. Intensive vannamei cultivation with low salinity greatly affects growth and survival rate [2]. However, salinity is a very basic environmental factor [3].

Based on the information above, the stocking density of vannamei plays a role in growth and survival. Therefore, it is necessary to conduct optimal stocking density research on vannamei shrimp culture with low salinity using tarpaulin ponds.

\section{OBJECTIVE}

The aim of this study was to analyze the growth and survival rate of vannamei that were cultivated in low salinity with different stocking densities using tarpaulin ponds.

\section{METHODS}

\section{A. Research Time}

The study was conducted in March-June 2018 at the Outdoor Laboratory of Study Program of Aquaculture. Lampung State Polytechnic.

\section{B. Materials and Tools}

1) Materials: The test shrimp used was Post Larva (PL) aged 11 days with an average weight of 0.005608 grams obtained from PT. Citra Larva Kalianda. The feed used was in the form of powder with a frequency of 4 times a day. Sea water obtained was from Teluk Hurun Pesawaran District, Lampung.

2) Tools: The tools used were a round tarpaulin pond with a diameter of 1 meter with a height of 1 meter as many as 9 pieces and an equipment of water quality measurement. 


\section{Research Methods}

The method used was direct observation (experiment) using a completely randomized design (CRD), three levels of treatment with three replications, with random media placement.

- $\quad$ stocking density of $175 \mathrm{shrimp} / \mathrm{m} 3$

- $\quad$ stocking density of $225 \mathrm{shrimp} / \mathrm{m} 3$

- $\quad$ stocking density of 275 shrimp/m3

\section{Research Procedure}

Shrimps used were acclimatized for 7 days in medium salinity of $35 \mathrm{ppt}$, with a decrease in salinity of 2-3 ppt per day to reach salinity of $10 \mathrm{ppt}$. Then, they were stocked into a tarpaulin pond with a diameter of $100 \mathrm{~cm}$ according to treatment. To reduce stress, the shrimp were firstly fastened for 1 day before being fed.

Shrimps were maintained for 60 days with feeding in the first month with blind feeding method [4], and in the second month with demand feeding $5-10 \%$ of biomass. To determine the growth and survival of shrimp, sampling was performed every seven days. Water quality measurements were carried out once a week. Parameters measured were temperature, salinity, $\mathrm{pH}$, and ammonia. While water management was carried out by siphoning and filtration treatments.

\section{E. Parameters Measured}

1) Mean Body Weight (MBW): Mean Body Weight (MBW) is the average weight of shrimp from the sampling results. MBW can be calculated as follows [5].

$$
M B W=\frac{\text { shrimp weight }}{\text { Number of shirmp }}
$$

Explanation:

$M B W$ : average weight of shrimp (gr/shrimp)

Shrimp weight: shrimp weight (gr)

Shrimp weight: Shrimp weight (gr)

2) Food Conversion Ratio (FCR): Food Conversion Ratio is the amount of food given to produce one $\mathrm{kg}$ of fish meat. FCR calculation used is as follow:

$$
F C R=\frac{F}{(B T+B D)-B O}
$$

Explanation:

$$
\begin{aligned}
& F=\text { Total feed (gram) } \\
& B T=\text { Total Final Weight }(\text { gram }) \\
& B D=\text { Dead fish weight }(\text { gr }) \\
& B O=\text { Total initial Weight }(\text { gram })
\end{aligned}
$$

3) Survival Rate (\%): Survival Rate (SR) is the survival of shrimp compared to the number of stockings and expressed by percent. Survival Rate (SR) can be calculated by the following formula [6].

$$
\operatorname{SR} \frac{N t}{N 0} x 100 \%
$$

Explanation:

$\mathrm{SR}=$ Survival rate of the shrimp (\%)

$\mathrm{Nt}=$ The final number of shrimp (shrimp)

$\mathrm{N} 0=$ The initial number of shrimp

\section{F. Data Analysis}

Data obtained from research results were presented in the form of tables and graphs. Data of growth and survival of tested shrimp were analyzed statistically. To see the effect of each treatment, Tukey test was conducted with a $95 \%$ confidence level $(\mathrm{P}<0.05)$.

\section{RESULT AND DISCUSSION}

\section{A. The growth of Vannamei Shrimp}

Mean body weight of vannamei shrimp was measured by sampling every 7 days by taking a sample at least $10 \%$ of each treatment and repetition. Vannamei growth data during maintenance with different densities are presented in the following table:

TABLE I. The WeIGHT (GRAM) OF VANAME Shrimp DuRING THE STUDY

\begin{tabular}{|l|c|c|c|c|c|}
\hline \multirow{2}{*}{ Treatment } & \multicolumn{5}{|c|}{ Observation day } \\
\cline { 2 - 6 } & $\mathbf{3 0}$ & $\mathbf{3 4}$ & $\mathbf{4 4}$ & $\mathbf{5 1}$ & $\mathbf{5 9}$ \\
\hline $\mathrm{A}$ & 2,41 & 3,61 & 5,02 & 9,54 & 10,5 \\
\hline $\mathrm{B}$ & 1,97 & 2,97 & 7,98 & 8,22 & 9,73 \\
\hline $\mathrm{C}$ & 2,03 & 3,12 & 5,11 & 6,41 & 8,5 \\
\hline
\end{tabular}

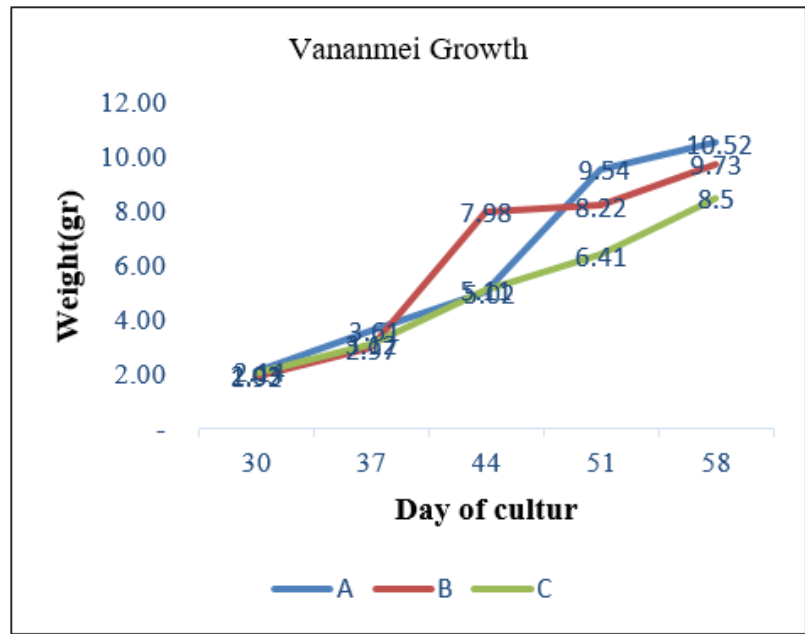

Fig. 1. Graph of mean body weight of vaname

The results showed that the best growth was the shrimp in treatment $\mathrm{A}$ and the lowest was the shrimp in treatment $\mathrm{C}$. This happens because high density will cause limited space and competition for food, living space and limited oxygen so that 
the average weight gain of shrimp produced at the end of the maintenance cannot be maximized [2].

Based on Figure 1, the stocking density had a significant effect on the growth rate of vanname. The highest growth of 10.52 grams was higher than the results obtained by Marlina E, et al which was 10.28 grams using 150 stocking density $/ \mathrm{m}^{2}$ [7]. There are several factors affecting the growth of shrimp in addition to internal factors, namely fathogen-free seeds and genetics, while external factors, namely feeding management and aquatic environment. Media salinity is one of the fundamental environmental factors [3], which influences shrimp metabolism in balancing the osmoregulation process appear from good growth in low salinity shrimp culture.

\section{B. Survival Rate}

The survival rate of shrimp had a significantly different value. The survival of shrimp in pond A was $91.39 \%$ then shrimp in pond B was $77.18 \%$ and the lowest was shrimp in pond $\mathrm{C}$ of $55.03 \%$. According Cahyono in Pratama A et al, factors that influence the high and low rates of life are abiotic and biotic factors [8]. Abiotic factors are physical and chemical parameters of water. The physiological process of the fish will run well if the living environment of the media is in the range that is capable of being absorbed, so as to maintain its life. The survival rate of shrimp in each treatment can be seen in the graph below.

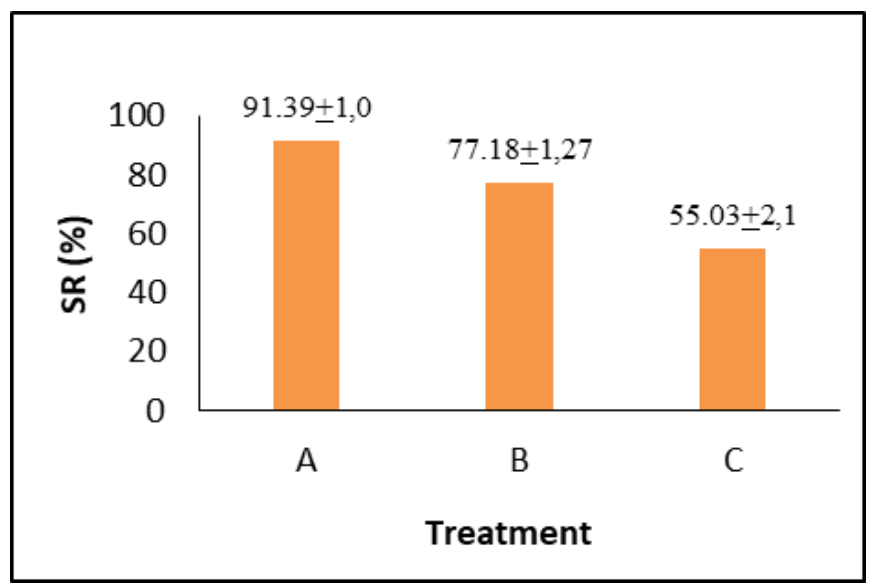

Fig. 2. Survival Rate of Vaname.

The survival of vanname was slightly significant. The shrimps that were kept in tarpaulin A obtained the highest survival rate $(91.39 \%)$ and the lowest was in shrimp in pond $\mathrm{C}$ $(55.03 \%)$. Thus stocking density affected the survival of shrimp. Based on the data above, the survival of vanname with stocking density of $175 \mathrm{shrimp} / \mathrm{m}^{3}$ (pond A) and $225 \mathrm{shrimp} / \mathrm{m}^{3}$ (pond B) can still be assumed to be good due to $>70 \%$ Marlina E et al. [7].

\section{Food Conversion Ratio}

Based on the results of this research, the conversion ratio of vanname maintained in round tarpaulin pond with different densities using low salinity media can be seen in the graph below:

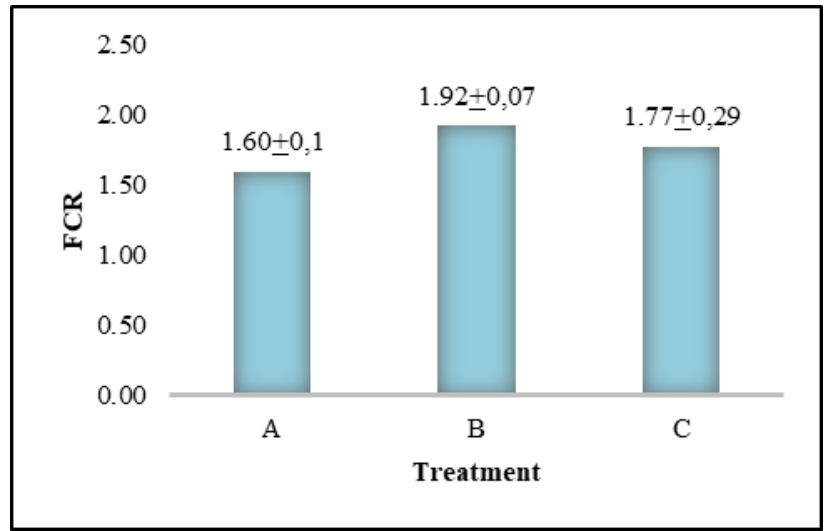

Fig. 3. Graph of feed ratio to growth of vaname.

The lowest FCR value was found in treatment A of 1.6, meaning that it requires 1.6 feed to produce one kilogram of shrimp. The resulting FCR value was still on the threshold quite well when compared with the results of Pratama A et al, [8], namely the resulting FCR of 1.9. A high FCR value was caused by a decrease in appetite, which can be caused by several factors, namely the decrease in plankton abundance and poor water quality. According to Effendi, unoptimal water quality will cause shrimp to experience decreased appetite, inhibition of the moulting process and susceptibility to disease [9].

\section{CONCLUSION}

Based on the results of the research that has been done, it can be concluded that shrimp stocking density maintained in low salinity tarpaulin ponds significantly affected the growth and survival of vanname. Optimal stocking density for maintenance of vanaamei shrimp in low salinity is 175 shrimp/m3. This is indicated by the highest growth yield of 10.25 grams, and survival rate of $91.39 \%$.

\section{REFERENCES}

[1] R. Jhonnerie, V.P. Siregar, B. Nababan, L.B. Prasetyo and S. Wouthuyzen, "Random forest classification for mangrove land cover mapping using Landsat 5 TM and ALOS PALSAR imageries," Procedia Environmental Sciences, vol. 24, pp. 215-221, 2015.

[2] P. Indah, P. Dewi, A. Maya and U. Fajar, "Pertumbuhan Udang Vanname (Litopenaeus vannamei) Di Tambak Intensif," Jurnal Enggano, vol. 2, no. 1, 2017.

[3] W. Gao, S. Emaminejad, H.Y.Y. Nyein, S. Challa, K. Chen, A. Peck, and D.H. Lien, "Fully integrated wearable sensor arrays for multiplexed in situ perspiration analysis," Nature, vol. 529, no. 7587, pp. 509-514, 2016.

[4] Supono, Teknologi Produksi Udang. Plantaxia. Yogyakarta, 2017.

[5] R.E. Johannes, "The renaissance of community-based marine resource management in Oceania," Annual Review of Ecology and Systematics, vol. 33, no. 1, pp. 317-340, 2002. 
[6] R.W. Haliman and D.S. Adijaya, Udang vaname. Penerbit Penebar Swadaya. Jakarta, 2005.

[7] M. Eulis, "Response of Vannamei Shrimp ( Litopenaeus vannamei) Growth In Salinity of $10 \mathrm{ppt}$ at Different Density," Proceedings International Conference of Aquaculture Indonesia (ICAI), 2017.
[8] P. Aan and S. Wardiyanto, "Studi Performa Udang Vaname ( Litopenaeus vannamei) Yang Dipelihara dengan Sistem Semi Intensif Pada Kondisi Air Tambak Dengan kelimpahan Plankton Yang Berbeda Pada Saat Penebaran," E-Jurnal Rekayasa dan Teknologi Budidaya Perairan, vol. VI, no. 1, 2017.

[9] Effendi, Pengantar Akuakultur. PT Penebar Swadaya. Depok, 2004 